\title{
The Stages of Igbo Conversion to Islam: An Empirical Study
}

\section{Chinyere Felicia Priest \& Egodi Uchendu}

Review of Religious Research

The Official Journal of the Religious

Research Association

ISSN 0034-673X

Rev Relig Res

DOI 10.1007/s13644-020-00402-5

\section{ONLINE FIRST}


Your article is protected by copyright and all rights are held exclusively by Religious Research Association, Inc.. This e-offprint is for personal use only and shall not be selfarchived in electronic repositories. If you wish to self-archive your article, please use the accepted manuscript version for posting on your own website. You may further deposit the accepted manuscript version in any repository, provided it is only made publicly available 12 months after official publication or later and provided acknowledgement is given to the original source of publication and a link is inserted to the published article on Springer's website. The link must be accompanied by the following text: "The final publication is available at link.springer.com". 


\title{
The Stages of Igbo Conversion to Islam: An Empirical Study
}

\author{
Chinyere Felicia Priest ${ }^{1} \cdot$ Egodi Uchendu ${ }^{2}$ (i)
}

Received: 17 May 2019 / Accepted: 23 February 2020

(c) Religious Research Association, Inc. 2020

\begin{abstract}
In recent years a very rare phenomenon was observed in Igboland, Southeastern Nigeria - the conversion of the Igbo to Islam. There exists a significant scholarly work on the stages of conversion or conversion process among different people group; however, to the best of our knowledge, little exists on the Igbo conversion to Islam. This could be as a result of the phenomenon being a relatively recent development in Igboland, commencing in the second half of the twentieth century (Uchendu in Soc Sci J 47(1):172-188, 2010). This article seeks to discover the stages of Igbo conversion to Islam; that is, the systematic phases involved in their conversion process to Islam To accomplish this, ethnographic interviews were conducted with thirty (30) former Igbo Christians, all now converts to Islam. Gerlach and Hine's (People, power, change: movements of social transformation, Bobbs-Merrill, Indianapolis, 1970) stages of conversion theory were applied to this study, and the findings showed that Igbo converts to Islam underwent six stages in their conversion process to Islam. These are: "Initial contact with a practicing Muslim; focus of need through demonstration; re-education through group interaction; decision and surrender; commitment event; and group support for changed cognitive and behavioral patterns (consequence)". The findings from this study reveal that tension and crisis do not often begin the stage of disaffiliating from one's original religion as some scholars claim. The study recommends that Igbo Christians should build strong ties with one another so that disaffiliation will not quickly occur.
\end{abstract}

Keywords Religion $\cdot$ Conversion $\cdot$ Islam $\cdot$ Igbo $\cdot$ Periods

Egodi Uchendu

egodi.uchendu@unn.edu.ng

Chinyere Felicia Priest

Felicia.priest@AfricaInternational.edu; feliciachinyere5@gmail.com

1 Department of Missions and Intercultural Studies, Africa International University, Nairobi, Kenya

2 Department of History and International Studies, University of Nigeria, Nsukka, Nigeria 


\section{Introduction: A Look at the Literature}

Many scholars have written significant works on the stages of religious conversion. Chief among them are Lofland and Stark (1965), Rambo (1992), Gerlach and Hine (1970), and Wallace (1956). Lofland and Stark's classical work provides answers to the question: why does conversion occur? Their proposed model of conversion, as reported, is "arguably the first authentically sociological model of religious conversion in the sense that it moves beyond a psychological conception of conversion to consider personal bonds and social networks" (Yang and Abel 2014, p. 142). Their model demonstrates seven stages an individual undergoes in a conversion process. These include: (1) experience enduring and acutely felt tensions (2) within a religious problem-solving perspective, (3) which leads him to define himself as a religious seeker, (4) encounter the movement or cult at a turning point in his life, (5) form an affective bond (or pre-exists) with one or more converts, (6) neutralize or break extra cult attachment where, if he is to become a deployable agent, (7) he is exposed to intensive interaction. The first three factors are classified as "predisposing condition", a condition an individual must experience before conversion while the last four factors are classified as "situational contingencies". This situation leads to conscription of the group and the acceptance of the group's worldview. Complete conversion will not occur without the situational contingencies, in spite of how predisposed the seeker may be (Lofland and Stark 1965, pp. 865-875).

Yang and Abel (2014, p. 142) refer to this disposing condition as the "microlevel"; that is, a level where "people turn toward religion when they lack something, either an "absolute" deprivation, such as bad health or poverty, or "relative" deprivation, as when people in any condition subjectively feel the lack of something". The individual with such deprivation easily changes his/her identity to another group through existing friendship or short-term friendships.

Rambo's conversion process differs slightly from Lofland and Stark's model. Rambo developed seven processes of conversion that also answer the question of why conversion occurs. These are:

(1) Context- "the total social, cultural, religious, and personal environment" of the potential convert. His/her disenchantment with the context. Meanwhile, the availability of options can "create perplexity and alienation... (such that) people may eagerly choose a new religious option to lessen anxiety, find meaning, and gain a sense of belonging";

(2) Crisis - this could be "religious, political, psychological, cultural, or a life situation that provides new options. At this stage, myths, rituals, symbols, goals, and standards cease to function well for the individual or culture. Such a crisis creates great disorientation in the individual's life";

(3) Quest - the search for meaning and purpose in life that intensifies under crisis or abnormal situations;

(4) Encounter-this "involves the contact between the potential convert and the advocate and takes place in a particular setting." The outcome of the con- 
tact is influenced by "compatibility of ideology, age, sex, education, and similar attributes." The needs of both the potential convert and the advocate, as well, are included in this stage;

(5) Interaction - the potential convert is exposed to "the teachings, lifestyle, and expectation of the group" through communication and social interaction;

(6) Commitment - the convert declares his involvement in the new religion explicitly and publicly through "biographical reconstruction, testimony, rituals, pain induction, decision making, and surrender"; and

(7) Consequences - the effects of his conversion on his ideas, relationships, and lifestyle (Rambo 1992, pp. 159-177).

Though Lofland-Stark and Rambo differ in their conversion processes, they agree on certain stages; Lofland-Stark stage one aligns with Rambo's stage two. Stages three and four (of both authors) are the same while others differ slightly. LoflandStark claim that their model is "universal" (Lofland 1966, p. 61), but Snow and Philips, working among Nichiren Shoshu Buddhist movement in America, proved them otherwise (1979, pp. 430-447). Rambo, however, acknowledges his model as not "universal and invariant" (Rambo 1992, p. 163). Both authors consider the conversion process from different disciplines: sociology and psychology, respectively.

Gerlach and Hine (1968) equally developed a conversion model to explain 'why' conversion occurs based on extensive ethnographic research among two groups- the Pentecostal and Black Power movements-in the United States of America (Gooren 2014 , p. 88). They discovered seven stages of the conversion process, which are

(1) Initial contact with a participant: A potential convert with predisposing tension converts to a new religion through personal contact with a participant in the new religion. This initial contact is achieved through already pre-existing important social relationships.

(2) Focus of needs through demonstration: This involves "redefining the potential convert's needs, desires, or discontents in terms of the specific ideology of the movement. At this stage, the individual observes changes, fulfillment, and satisfaction in the life of a relative or friend who joined the movement and knew that he/she can experience the same.

(3) Re-education through group interaction: To maintain and sustain commitment, the convert must identify with the values of the movement to grow through group interaction; commitment cannot be sustained in a vacuum. If external relationships are neutral or weak, the potential convert will quickly bond with the new religion through relationships with its members. This is similar to LoflandStark interaction stage.

(4) Decision and surrender: At this stage, the convert surrenders the old identity and transfers control to something outside the individual's consciousness. In Christian theology, this is looked upon as repentance or acceptance of Christ as Savior. It is a crucial point in commitment, whether the commitment was coerced or persuaded.

(5) The commitment event: An event to which commitment can be traced is in the experience of salvation (within Christian circles) and the act of Baptism in the 
Holy Spirit that "symbolize a turning away with finality from things and people associated with one's former role which in many cases actually provide the skills and initiate the behavior patterns expected in the new social role". Commitment comprises four major elements: strength of conviction, capacity for risk-taking, personal charisma, and behavioral change.

(6) Testifying to the experience: a convert is encouraged or pressured to share his/ her experience with the group publicly. As Gerlach and Hine observe:

Talking about their subjective experience effectively clarifies and reifies it for the individual and draws immediate reinforcement from the group... and 'fixes' it as a reality, both for the convert and for his group. Without this step in the commitment process, much of the transforming effect of the commitment event would be lost. (1970, p. 136)

(7) Group support for changing cognitive and behavioral patterns: Converts are warned of subtle satanic opposition through family and friends. "Doubt, as well as other psychological and physical trials, are attributed to this source. Support from other members during this period is essential" (Gerlach and Hine 1970, pp. 111-37).

The three scholars referenced here all developed seven stages (or factors) of the conversion process, which both differ at some points and are parallel at others. The trio adopted different terms for each stage, but are unanimous in the area of 'interaction'. Rambo admitted that his is a "modification of the work of Tippet as well as Lofland and Stark's models" (Rambo 1992, p. 163). The outstanding point in all these models is that potential converts undergo certain processes before conversion, and these validate the popular claim that conversion is a gradual process in most cases. All the processes do not occur in a moment; rather, they occur gradually, over a period of time, as the convert considers his losses as well as the benefits of converting.

Stages three (re-education through group interaction) and five (the commitment event) of Gerlach and Hine's model are considered very crucial in determining if a genuine personal conversion has occurred. Gerlach and Hine's model is helpful in understanding the individual conversion process and also religious organization movements. Their model, which they believe to be universal, identifies the following five important factors in establishing religious and social movements: (1) personal commitment, constructed along the seven factors or stages in the conversion process; (2) enthusiastic persuasion of friends, relatives, and neighbors to join in the small-scale effort; (3) articulation of beliefs and ideals appropriate to the contemporary period of national and world history; (4) building flexible, non-bureaucratic cell-group organizations which can be created, altered, or dissolved at the desire of participants; and (5) expectation of and willingness to face opposition from those dedicated to the maintenance of the status quo (Gerlach and Hine 1968, pp. 23-40).

"Anthony Wallace developed a model to explain periods of accelerated cultural change by looking at the crucial role of movements like Handsome Lake, Peyote, and Ghost Dance in North America" (Gooren 2014, p. 85). He expounded upon a theory that is connected to conversion, and which he labeled 
"mazeway". He explains: "The mazeway is nature, society, culture, personality, and body image, as seen by one person" (Wallace 1956, pp. 266-267). Mazeway is, therefore, crucial in the conversion process of an individual. Wallace theorized a universal model that describes stages all revitalization movements, including individuals, ought to go through. These are (1) Steady state-a culturally recognized efficient technique for satisfying needs and reducing stress within a system that already exists. "The techniques for satisfying other needs are not seriously interfered with, and abandonment of a given technique for reducing one need in favor of a more efficient technique does not leave another need, which the first technique satisfied, without any prospect of satisfaction." (2) The period of individual stress - this is a point where individual members of a population begin to experience decreased efficiency in the techniques of stress reduction caused by external factors like economic distress, climatic change, epidemics, among others. He/she tries to tolerate the inefficiency, but it gets to a point where he/she starts considering alternatives or substitutes. The initial consideration of a substitute arouses stress because of the anxiety that the substitute may be less effective than the previous technique and because accepting the substitute may hinder the execution of other ways. (3) The period of cultural distortion-at this stage, the prolonged experience of stress caused by the decrease in the efficiency of a stress-reduction technique and anxiety of the prospect of substitution (or changing a behavioral pattern) are responded to differently. People with a rigid personality will continue to endure and undergo the intensified stress, while flexible people will add and substitute to cope or adapt to the change. The various responses (aggression or aggressive behaviors) become a new culture, the culture then become "internally disoriented". Finally, when the inefficiency of the techniques becomes more and more obvious, and the anxiety of substituting a meaningful way of life becomes equally obvious, then disillusionment with the mazeway sets in. (4) The period of revitalizationthis is the most crucial phase because the deterioration can lead to the death of the society or movement. These movements must perform the following six important tasks at this stage to survive mazeway: communication, organization, adaptation, cultural transformation, and routinization. Lastly, (5) The new steady state-once cultural transformation has been accomplished, the new cultural system has proved itself viable, and the movement organization has solved its problems of routinization, a new steady state may be said to exist. The culture of this state will probably be different in pattern, organization or Gestalt, as well as in traits, from the earlier steady state, and it will be different from that of the period of cultural distortion (Wallace 1956, pp. 265-275).

In conclusion, anthropologists, historians, sociologists, and psychologists have grappled, and are still grappling, with defining and explaining religious conversion. This demonstrates that the conversion phenomenon is a complex one and no single discipline, model, or motif has been able to explain it adequately. Disaffiliation involves a good number of levels that a potential convert undergoes to become an adherent of a new religion, as discussed in this section. 


\section{Periods of Conversion among Igbo Converts}

The Igbo are one of three major ethnic groups in Nigeria. The word Igbo (previously also called Heebo, Iboe or Ibo) refers both to the name of the group and their language. With an estimated population of thirty-three million in 2017 of those domiciled in Nigeria, they account for nineteen per cent of the country's population (CIA World Factbook 2017). A unique feature of the group is their economic and migratory tendencies, which is informed by land shortages and population explosion and dates back to the ninth century (Ohadike 1994, p. 15). These continued, being responsible for numerous significant diaspora communities in different parts of Nigeria and in many parts of the world since the twentieth century. The Igbo are found both in the Southeast, regarded as the homeland, and in the Southwest. This study is focused entirely on the population in the Southeast of Nigeria.

The current research is based on the analysis of interviews conducted with thirty (30) Igbo converts to Islam drawn from different parts of Igboland (Enugu, Owerri, Enohia in Afikpo North, Nakanu in Afikpo and Afikpo town, Obollo Afor, Imilike Enu and Imilike Ani, Ibagwa, Nsukka and Okija). These sites were chosen in order to investigate if the same factor influences conversion in all the regions or whether some factors are peculiar to certain regions.

The sample consists of twenty-three (23) males and seven (7) females. Their age ranged from 23 years and above. The imbalance between the numbers in gender is most likely a result of the method used in selecting participants. The interviews were conducted during Ramadan and in the mosques before and after prayers; fewer women than men joined in these activities. Again, those referred to the researcher by the Chief Imams and a few other referrals were mostly men also. Most importantly, the conversion phenomenon in Igboland seems to be occurring more among men than among women. All the female converts (except one) interviewed in this study converted to Islam as a requirement to marry their present husbands. This indicates that these women may not have converted to Islam if not for marriage. Their conversion, therefore, was social pressure but existed and functioned as support. For obvious reasons, the names of interviewees and other collaborators in this study have been withheld.

By way of demographics, twenty-two converts were married (nineteen were already married to the members of the old religion prior to their conversion while three married members of the new religion), six unmarried, one engaged to be married, and one did not specify his marital status. As mentioned, they were contacted through the Chief Imams, referrals and personal recruitment. Before each interview, the interviewee was informed that the information they provide would be used for this academic purpose. With their permission, tape-recorded interviews were held with individual converts for periods ranging from forty-five minutes to two hours.

In 1970, Gerlach and Hine expounded a profound conversion model based on their survey of Pentecostalism in the United States. Their seven-step model, discussed in the preceding section, will now be applied to Igbo converts' experience in this section. 
All thirty converts reported having been Christians prior to conversion. Twentyseven of the thirty converts claimed to have been practicing Christians prior to conversion, while two reported that they were not practicing Christians prior to conversion. The converts are categorized into three: those who claimed to have been weak and nominal Christians before their conversion, those who reported that they were committed Christians prior to conversion, and those who stated they were young prior to conversion and, thus, knew little about Christianity.

Category 1: weak and nominal Christians (14) - fourteen converts considered themselves weak and nominal Christians prior to conversion. These converts attended church on Sundays only and were not seriously involved with other activities of the church. Religion, for them, was merely something called Christianity, Islam or Hinduism, but they became transformed after their conversion to Islam. The following statements illustrate their nominalism:

I was a member of the Anglican Church; that is where I was baptized. I was born and bred in that church as I found my parents, though they were not committed. They were not committed, but any time there was any festivity in the church, they would invite my father, and he would go. But on Sundays, we did go there and worshipped. (Convert 25)

I was a Christian, but, as a Christian then, I could not understand it because I could not pray enough. Those I was walking with then, we would move from church to beer parlor. That time I drank a lot, I drank so much and womanized very well. I know how much I spent on drink and women then. (Convert 10)

Category 2: Committed Christians (13) — thirteen converts considered themselves committed Christians while in Christianity. They had a clear understanding of the evangelistic perception of what it means to be a Christian. Some, by their testimonies, had even accepted Jesus Christ as their Lord and Savior. Those in this category attended church regularly, including weekly services, were baptized (infant baptism), received the Eucharist, participated in the activities of the church, contributed towards the projects of the church, belonged to one or two groups in the church and taught catechism. One was undergoing training to become a Reverend Father. These converts (except two males) became disenchanted or disillusioned with Christianity and changed to Islam. Their disillusionment was not with the theological beliefs or practices of Christianity, but with the attitude and behavior of some Christians and pastors. Below are a few examples from the converts. A convert averred that

Christians believe that Jesus is their Lord and personal Savior and that He is the Son of God. So that as a Christian, you need to believe in Jesus and as well be born again. Yeah, I believed in that, and I was in the intercessory arm of the church (Convert 22).

I was baptized, confirmed, and received Eucharist in the Catholic Church. I was one of those who instituted carols during Christmas in my village Umuomi Uzoagba. My life has been pure in Christianity, I was a mass servant, and my Reverend Father used to call me, "Anthony, talk to them" i.e., the mass servants who were misbehaving... their behavior was rubbish. The 
Reverend Father would call me to talk to them because of my character and my quality (Convert 16).

Category 3: Young Christians (3)-This third category covers the three converts that considered themselves young when they were Christians and, therefore, knew little or nothing about Christianity. One convert reported: "When I was a Christian I would say it was during my childhood, though I was not a stubborn or rebellious person right from that time (Convert 12). Another stated,

When my parents were Christians (they still are) at that time, I did not know much; I was still a young, growing boy. So, I will not talk much concerning Christians. (At) that time, I was about 14 years. At least a child of about 14 years (at) that time knows nothing. Not that he knows nothing, but he knows nothing concerning religion (Convert 4).

Twenty-three Igbo converts, out of the thirty interviewed, reported going through Gerlach and Hine's first process of conversion, which is initial contact with a participant. All twenty-three converts confirmed that their initial contact with Islam was through a Muslim. These initial contacts with Muslims are classified into five categories: First were those who came into contact with Islam through their spouses (five females). Second were those who came into contact with Islam through family members or relatives - this includes brothers, brothers-in-law, kinsmen, and a maternal uncle (eight males). The third group came into contact with Islam through friends, colleagues, or neighbors (13 males). The fourth came into contact with Islam through Daily Times newspaper in Nigeria (one male). Finally, the fifth group includes those who came into contact with Islam through unique processes, including direction from God via dreams (two males). One of the two converts reported this process. According to him, "No Muslim knew me before I entered Islam; any Muslim that knows me knew me when I entered Islam. It is God that brought me into Islam" (Convert 16).

Therefore, Gerlach and Hine's (1970) first stage of conversion 'contact with a Muslim participant' is highly evident in the Igbo Christian conversion process to Islam.

A second set of seven interviewees' (six males and one female) conversion stage from Christianity to Islam began with context, which implies that they were disenchanted with their context, religion, culture, society or personal environment. They had crises such as frustration for lack of employment, maltreatment of Christians, and sickness. Two expressed having had a quest for meaning and purpose in life.

The second process, focus of needs through demonstration, was reported by four converts (three males and one female). They reported to have observed positive change, fulfillment, and seriousness with the things of God in the life of their Muslim friends, relatives, colleagues, or neighbors. For example, one convert stated:

I started observing some characteristics in their (Muslims friends) lives, which are quite different from mine: they were not living as sinful as I was. After a while, I started liking Muslims, and no one preached to me. It was just their character that influenced me to join Islam (Convert 13). 
This shows that Islam can influence a change in a person's life; that Muslims engage in da'wah (preaching) through their lifestyle; that non-Muslims generally but, in this case, Christians, observe how Muslims live their lives; and that Igbo Christians have relationships with Igbo Muslims.

In the third stage, re-education through group interaction, seventeen converts stated that they were taught Islamic values, ideology, beliefs, and practices. They began practicing Islamic teachings, like praying five times daily, and observing Islamic laws, such as abstinence from drinking alcohol, smoking, and eating pork. They also accepted Islamic ideology on the monotheistic nature of Allah. On this, Convert 13 also stated: "they (Muslims) began explaining certain things (about Islam) to me, so one day I just decided to embrace Islam." Another convert reported that his brother-in-law, whom he was living with, taught him the history of Islam. With respect to this stage, Gerlach and Hines (1970) postulated that if external relationships are neutral or weak, the potential convert will quickly bond with the new religion. This appears to be applicable in this study as some converts reported that they had stopped attending church for about a year and others stated they had no strong ties with Christians, except their childhood friends. This neutral state, or weak bonds with Christians or the church, resulted in easy abdication to Islam. One convert narrated his experience as follows:

During that period, I was not even going to any church. In short, since I went to Lagos, I never attended church .... When he (Muslim friend) was close to me, he was telling me about Islam, teaching me how to read Qur'an in Arabic, and telling me that Islam is the right road to worship God. During that time, he had pulled me down. (Convert 9)

The converts were re-educated through preaching, teaching, explanations, and donations of materials to read about Islam; reinforced with material and financial support. The outcome of their re-education was their eventual decision and surrender to Islam. This stage parallels Rambo's (1992) interaction stage.

The fourth stage, decision and surrender, was present in the narratives of the thirty converts sampled. At the end of these converts' studies about Islam, their observation of the Muslim lifestyle, and on occasion even coercion, they surrendered their old identities and embraced Islam. The following narratives support this point:

He (Muslim) supplied me with textbooks, and after reading the textbooks, because I had my belief then as a Christian, I have my own belief. So after reading the textbooks and those things in the textbooks that aligned with my own belief, I said, 'Okay, this particular religion I will give it a try let me see if it's actually the religion of God' (Convert 11).

Then I came back here (mosque); I was with him (a friend). So many of his Muslim brothers were forcing me to convert to Islam. I said, 'no.' So they were like trying to push me for roughly a month, and then one day, I just decided to make up my mind and embrace the religion. (Convert 3 ) 
These reports show that converts reach a point where they surrender their old identities in their conversion journey. This may happen intentionally, or through pressure exerted by religious agents as in the case of Convert 3 above.

The fifth process, the commitment event, was experienced by all thirty converts sampled. They performed some rituals to symbolize their turning away with finality from Christianity and from things and people associated with their former roles as Christians. This event included: taking the 'shahada' (public declaration of their acceptance of Islam), change of name, and induction through taking a ritual bath (the Igbo converts to Islam call this bath baptism). This parallels Rambo's commitment stage.

The sixth stage, testifying of the experience, was absent in the converts' conversion process narratives. Although this stage appears absent in the data, since no question was specifically asked on this topic, it is nonetheless present. Instances of public video testimonies of conversion have been recorded and widely circulated on social media, especially on Whatsapp and YouTube, in the last one year. A popular testimony shared in April 2018 was given by a former pastor-turned-convert to Islam from Ebonyi State. He narrated how he moved from hating Islam to accepting Islam. One thing that happened, he testified, was his dream encounter with Allah on the night he had a misunderstanding with his General Overseer. He saw himself, in the dream, surrounded by five bearded and turbaned men, who all the while were reciting la ila ila la. He went further:

In that trance, I was also reciting la ila ila la. ... Afterwards, I met a [Muslim] youth corper, told him my dream and asked him to give me the interpretation of that dream... He told me: 'Pastor, maybe Allah is calling you?' That dream kept ringing in my memory, and I was always reciting la ila ila la. That was how I became a Muslim." (Source: "Nigeria: Christian Igboman Converts to Islam in Public. Hear Him Out." https://www.youtu be.com/watch? $\mathrm{v}=\mathrm{fMKoS} 5 \mathrm{DxFMQ})$.

The seventh stage, group support for changing cognitive and behavioral patterns, appears to be present in the experience of all the converts sampled. Rambo termed this stage 'consequence.' The converts reported that their conversion resulted in negative consequences from family members and their society which included: ridicules, threats, insults via name-calling like onye Hausa (an Hausa man or woman, symbolizing a foreigner), ndi allakuba (those who hit heads on the ground); rejection, quarrels, hatred, estrangement, deprivation, isolation, keeping malice, attempted murder, abandonment, dissolution of marriage, fighting, enmity, being perceived as an enemy, anger, and others.

Out of Gerlach and Hine's (1970) seven steps stage model of conversion process, six were applicable to this study and all of Rambo's (1992) seven stages of process were present in this study too, but in fewer cases. Five out of seven of Rambo's stages of conversion applied to this study. It paralleled Gerlach and Hine's five of the seven conversion processes reported in this study. So, when these paralleled stages from both scholars are considered, it indicates that only five of their conversion process model is significant and applicable to this study. However, Garlech's and Hine's were reported, or experienced, by more converts. 
So the difference between these scholars' models is that Rambo's stages one and two were absent in Garlach and Hine's projections. Likewise, Gerlach and Hine's stages four and six were absent in Rambo's model. Despite these slight variations, this study shows that most of Garlech-Hine and Rambo's models were applicable, but at varying degrees, in the Igbo conversion process to Islam.

\section{Conclusion}

The essence of this article was to trace the progression of Igbo conversion to Islam. Review of some related literature showed that potential converts undergo seven stages of the conversion process before conversion finally occurs. They include: (1) contact with a participant in the new religion, (2) crisis that results to discontent with the individual's present situation, (3) re-education into the value, philosophy, and belief of the new religion, (4) decision and surrender at which the seeker surrenders the old identity and transfers control to something outside the individual's consciousness, (5) commitment event to which commitment can be traced, (6) testifying to the experience when the convert publicly shares his experience with the group, and finally (7) consequences which is the effect of the conversion on the convert. This comes in the form of rejection from the family, name-calling and disassociation from the community.

In the case of Igbo Christian converts to Islam, six periods were evident from the population sampled and these were: contact with a participant in the new religion, focus of need through demonstration, re-education through group interaction, decision and surrender, commitment event, and consequence. The testimony stage, which was not identified because no direct question was posed on it, was, however, reported via other channels. It is, therefore, recommended that students of conversion studies should adopt Gerlach and Hine's theory in other contexts for further discovery of its generalability. The study also shows the need for Igbo Christians to build strong ties with one another so that disaffiliation would not easily occur leading to desertions, and churches should show genuine interest in the welfare of their members, not to mention the need for the gospel to be preached to reduce disaffiliation.

\section{References}

Central Intelligence Agency. 2017. The World Factbook. https://www.cia.gov/library/publications/theworld-/factbook/. Accessed 24 July 2018.

Gerlach, Luther P., and Virginia H. Hine. 1968. Five Factors Crucial to the Growth and Spread of a Modern Religious Movement. Journal for the Scientific Study of Religion 7(1): 23-40. https://doi. org/10.2307/1385108.

Gerlach, Luther P., and Virginia H. Hine. 1970. People, Power, Change: Movements of Social Transformation. Indianapolis: Bobbs-Merrill. 
Gooren, Henri. 2014. Anthropology of Religious Conversion. In The Oxford Handbooks of Religious Conversion, ed. Lewis R. Rambo and Charles E. Farhadian, 84-116. Oxford: Oxford University Press.

Lofland, John. 1966. Doomsday Cult. Englewood Cliffs: Prentice Hall.

Lofland, John, and Rodney Stark. 1965. Becoming a World-Saver: A Theory of Conversion to a Deviant Perspective. American Sociological Review 30: 862-875.

Ohadike, D. 1994. Anioma: A Social History of the Western Igbo People. Athens: Ohio University Press.

Rambo, R.Lewis. 1992. The Pyschology of Conversion. In Handbook of Religious Conversion, ed. Newton Malow and Samuel Southhard, 159-177. Birmingham, AL: Religious Education Press Inc.

Snow, David A., and Cynthia L. Phillips. 1979. Lofland-Stark Conversion Model: A Critical Reassessment. Social Problems 27: 430.

Uchendu, Egodi. 2010. Evidence for Islam in Southeast Nigeria. The Social Science Journal 47(1): $172-188$.

Wallace, Anthony F.C. 1956. Revitalization Movements. American Anthropologist 58(2): 264-281.

Yang, Fenggang, and Andrew Stuart Abel. 2014. Sociology of Religious Conversion. In The Oxford Handbooks of Religious Conversion, ed. Lewis R. Rambo and Charles E. Farhadian, 140-163. Oxford: Oxford University Press.

Publisher's Note Springer Nature remains neutral with regard to jurisdictional claims in published maps and institutional affiliations. 